\title{
THE MEASUREMENT OF WORK STRESS WITHIN SOUTH AFRICAN COMPANIES: A LUXURY OR NECESSITY?
}

\author{
EBBEN VAN ZYL \\ Department of Industrial Psychology \\ University of the Free State
}

\begin{abstract}
The measurement of work stress within South African companies: a luxury or necessity? South Africans seem to be experiencing various causes of and very high levels of stress. To reduce the costs of stress within the South African organizational context, more attention should be paid to the measurement of stress which can serve as a starting point for the handling of stress. The first step towards determining levels and causes of stress within and outside the organizational context, is to acknowledge different responses to stress across various cultural groups. Furthermore it is important to see the measurement of stress as a process. Various methods of measuring stress are discussed. Attention is also devoted to the question as to which group to start with.
\end{abstract}

\section{OPSOMMING}

Suid-Afrikaners blyk 'n verskeidenheid oorsake van stres en baie hoë vlakke van stres te ervaar. Om die koste van hoë stres binne die Suid-Afrikaanse organisasiekonteks te verminder, is dit belangrik om meer aandag aan die meting van die stres te gee wat kan dien as ' $n$ beginpunt om stres sinvol te hanteer. Die eerste stap in die meting van vlakke en oorsake van stres binne en buite organisasieverband, is om die verskillende response van die onderskeie kulturele groepe te erken. Verder is dit belangrik om stresmeting as 'n proses te beskou. Verskillende metodes van stresmeting word bespreek. Aandag word ook gegee aan die vraag met watter groep begin moet word.

People in this modern era are increasingly threatened by psychological stress, due to aspects such as over-population, competition, economic crises, lack of meaningful relationships, time pressures and so forth (Pienaar, 1998, p.1; Van den Bergh, 2001, p.3). Jacobs $(2001$, p.1) puts it as follows: "Stress is a reality of life, it is unavoidable, good and bad, constructive and destructive." The destructive nature of stress is reflected in its cost side. To reduce the costs of stress in South Africa, more attention should be paid to the measurement of stress within the organizational context.

\section{LEVELS AND CAUSES OF STRESS IN SOUTH AFRICA: THE CURRENT SITUATION}

An investigation conducted in South Africa (Van Zyl, 1993), indicated that $34,7 \%$ of Coloureds, $38,1 \%$ of whites and Asians and $35 \%$ of black South Africans suffer from high stress. In Europe and the USA approximately 10-22\% of people experience high levels of stress (Van Zyl, 1993; Karasek \& Theorell, 1990). In comparison with overseas countries, South Africans therefore experience abnormally high levels of stress.

The following statistics and probable symptoms of stress confirm the tendency towards high stress among South Africans (Bews, 1998; Pienaar, 1998, Van den Bergh, 2001):

- South Africa's divorce rate is one of the three highest in the world.

- The incidence of coronary diseases is among the five highest in the world.

- Until recently the suicide rate among the Indian community was the highest in the world.

- There are too many people in jail.

- The number of motor accidents is among the highest in the world.

- The use of drugs was among the highest in the world, especially in the Western Cape.

A popular newspaper summarises the situation in the following headline: "We are in a mess, over stress" (McGarvey, 1995).

Requests for copies should be addressed to: E van Zyl, Department of Industrial

Psychology, University of the Free State, PO Box 339, Bloemfontein, 9300
There are a number of reasons for the high stress that South Africans are experiencing. Increased demands being forced on South Africans, inside and outside the work situation, as well as a lack of ability to handle these demands, most probably give rise to the negative situation (Van Zyl, 1997, p.138). Demands within the work situation have increased because of, inter alia, the current economic situation in the country. This situation leads to the following:

- Fear of retrenchment and lower income. Retrenchment leads to a lowering of financial position and status. Furthermore, the self-confidence and self-esteem of those involved are influenced negatively. The Suicide Prevention Centre has noticed a drastic change in the underlying causes of people wanting to commit suicide. Previously the main reason was problems with a relationship. Now the central worry is money: panic about losing the house, the car being repossessed, people gambling in the hope of getting money and losing what they have, etc. (Van Zyl, 1993).

- Fear that individual or business objectives will not be reached. In order to realise objectives, employees overload themselves or are overloaded. A number of cases are known of employees working up to 90 hours per week on a continuous basis (including weekends), which means that more or less $80 \%$ of their non-sleeping hours is spent working. Gerber, Nel and Van Dyk (1999) and Carstens (1989) claim that the average South African employee works $15 \%$ longer hours than his Australian counterpart. Research also revealed that the average South African employee has a 49hour working week, compared to a 38,8 hour week in Japan, a 35 hour week in the USA and a 31,6 hour week in Germany (Carstens, 1989, p.4).

- Unhealthy competition among employees that may lead to conflict, aggressive behaviour, poor communication and low morale (Van Zyl, 1997).

Increased demands and accompanying high stress are carried over to the non-work situation. Kruger (1988, p. 92) explains it as follows: "It is acknowledged that work stress creates an emotional climate that can be transmitted to the home and affect the dynamics of family life." Work stress affects not only the employee, but spills over and influences other people with whom the individual interacts, such as spouse and children. Work stress has been related to the marital relationship, to parenting and psychological adjustment. 
Increased demands outside the work situation are accompanied, inter alia, by racial tension and political pressures that are unique to South African conditions (Pienaar, 1998). These increased demands and accompanying higher stress are, in turn carried over to the work situation. It appears, for example, that political pressures and racial tension have contributed to a greater incidence of work-related strikes. According to Pienaar (1998, p.8) strikes are stressful for any employer since it is usually accompanied by

- a decline in productivity and a loss of income; and

- cases where some employees then have to work overtime and consequently have to be rewarded; and

- bad publicity for the company.

New legislation (for instance the Employment Equity Act) stipulates that within South African organisations the working corps has to be representative of all racial groups in South Africa. This puts the additional burden and stress on employers to achieve that goal, sometimes even to the disadvantage of capable workers who cannot be selected or promoted.

South Africans' lack of ability to handle high stress is reflected especially in the already discussed reactions and symptoms of stress. Unfortunately, many South African public and private companies still do not realise what an effect chronic stress can have on their employees. It is therefore not seen as a priority to develop their employees' ability to handle stress. Mojalefa (1991, p. 2) suggests a further reason: "It seems that although some employers know the facts about stress, they still find it very difficult to do something concrete to reduce the amount of stress in their employees' lives. Reasons for this can be the fact that health professionals have been approaching the problem in a very fragmented and uncoordinated manner."

To summarise, South Africans seem to be experiencing various causes of and very high levels of stress. One way of addressing the problem is to pay more attention to the measuring and management of stress within an organizational context.

\section{THE NEED FOR ASSESSING LEVELS AND CAUSES OF STRESS WITHIN ORGANIZATIONAL CONTEXT}

It seems that stress and related health problems result in great costs within organizational context. In this regard Everley \& Fieldman (1991, p. 6) state: "This relentless upward spiral of health benefit costs is taking its toll throughout industry. Each year corporations are forced to allocate a large share of their operating expenses just to provide employee health benefits, resulting in higher consumer prices or lower profits, or both."

The direct costs of stress and the resulting poor performance show up in a number of ways. Numerous research studies (Ivancevich, Mattheson 1996; Carstens, 1989; Quick, Murphy and Hurrel, 1992; Jacobs, 2001) have shown that individuals experiencing stress make errors, are absent more often, must be replaced more frequently, are involved in work accidents, strikes as well as work slowdowns. It has been estimated that South Africa loses roughly R500 million each year just in absenteeism and to a loss in productivity (National Council for Mental Health, 1991).

Indirect costs include the question of the cost of lost opportunities. Research (Schaufeli, Maslach \& Marek, 1993) demonstrates that stressed employees are less creative, less effective decision-makers and inadequate communicators. Who can say what an organization might gain by a $3 \%$ increase in decision-making effectiveness or a $5 \%$ increase in creativity? Other indirect costs due to high stress can include a lack of confidence in management and colleagues, poor labour relations, low morale, etc.
Because of the already discussed costs that can accompany high stress, the importance of stress management within organizational context cannot be over-emphasised. Stress measuring in particular, should form an important starting point in the stress management process for the following reasons:

- Stress management can only be effective if the focus falls on specific problem areas within the organization and on the needs of people. Management strategies should be problemand need-oriented to gain a good understanding of the kind of problems that have to be attended to. Van Selm (1990, p.3) stresses the following point: "A clear understanding of the particular stressors in an occupational setting is important." Development of an occupational stress programme by identification and assessment of the stressors particular to the environment (inside and outside the work situation) and the levels of stress in that environment, must be addressed. Mojalefa (1991, p.4); Simms, (1994) elaborates on this by saying: "For organizations to provide a service that will be of benefit to its employees as well as meeting the company's broad objectives of productivity, it is essential to gain a good understanding of the kind of problems that have to be attended to."

- Scientific stress measurement and making known its results in a confidential and responsible manner could motivate people to become involved in stress management actions. In Rehabilitation in South Africa (1991) it is stated as follows: "A major problem amongst employees is that those suffering from stress, seldom recognize it and do not want to get involved in coping strategies." Jacobs (2001, p. 33) remarks: "It is one thing to convince workers that stress is harmful; it is another to help them recognize signs in their own behaviour." Strumpher (1995, p. 66) summarises it rather comprehensively: "According to research, the measuring of stress heightens involvement, provides a database upon which the participants can further their understanding of how stress relates to them, and generally reinforces both learning and transfer." Strumpfer, however, cautions that participants should always be assured of the confidentiality of such data and that they should feel no direct or indirect pressure to share them with anyone.

Other advantages that stress measurement may hold for private and government enterprises include the following (Van Zyl, 1997):

- Stress measuring allows companies to respond in a preventive manner to identified problem cases and areas that can reduce or eliminate direct and indirect costs. Employees who manifest symptoms such as depression, burnout and phobias, as well as a lack of performance and productivity, are most probably already influenced negatively and this could have been prevented.

- Jacobs (2001, p. 63) stated that many South African companies are dealing with stressors in a symptomatic and in a reactive way. In her opinion, if more pro-active measures could be taken, the psychological and social health of organisations as a whole could be improved. This could have the following beneficial results:

- A confrontation of poor performance

- An orientation of "work the problem" and not "find the culprit"

- The consideration of the importance of conflicts to decision-making and personal growth

- Collaboration throughout the organization

- The focusing on personal needs and human relationships in tackling problems

- The respect of people's judgement lower down in the organization

- A sharing of responsibility (in other words a noticeable sense of team-playing in planning, in performance and discipline)

- A more flexible leadership, shifting in style and person to suit the situation. 
- Stress measuring provides companies with firm ground to stand on should claims due to stress-related illnesses be submitted. By determining all their employees' levels and causes of stress comprehensively and scientifically and by acting in accordance with these results, unnecessary costs can be reduced.

Nykodym \& George (1989, p. 57) state: "In several court cases based on work-related stress charges, the USA companies involved lost their cases and paid settlements; this has resulted in direct monetary loss as well as in the loss of employees." In South Africa, similar claims may be submitted due to higher demands made on employees.

- Stress measuring may serve as an aid in determining the efficiency of the stress management programme. By applying stress measuring before and after the stress management programme, an indication of whether stress levels have decreased or whether the causes of stress have been reduced may be obtained.

From the preceding discussion it is quite clear that stress measuring ought to be an important priority in any organization. The question is: "What process and method should be implemented to measure stress?" This issue will be elaborated on in the next section.

\section{DETERMINING LEVELS AND CAUSES OF STRESS WITHIN AND OUTSIDE ORGANIZATIONS}

The acknowledgement of different responses to stress Supervising personnel should develop a sensitivity to different people's typical reactions towards high stress. Action can then be taken in good time to reduce employees' high levels of stress. In Rehabilitation in South Africa (1991), the following signs of high stress are listed for use by supervisors:

- A sudden high incidence of absence from work

- A sudden tendency towards isolation and withdrawal

- Initiative and creativity suddenly decrease a lot

- Person is moody and has emotional outbursts

- Person is hyper-sensitive to criticism

- Person has a sudden loss of drive and motivation

- Person suddenly becomes absent-minded.

Jacobs (2001, p. 2) as well as Levert, Lucas \& Ortlepp (2000), gives the following warning signs of high levels of stress:

- Frequent illness

- Persistent fatigue

- Irritability

- Nail-biting

- Lack of concentration

- Increased use of alcohol and drugs

- Poor interrelationships.

The question now is "can the warning signs of high levels of stress be made applicable to all racial and cultural groups in South Africa?"

Pienaar $(1998$, p. 81) is of opinion that the broad spectrum of warning signs of high stress can indeed be made applicable to all racial/cultural groups, because there is strong evidence to suggest a basic unity of people across different groups, which is reflected partly in common personality types and common forms of psychological disturbance among people. However, there might be however, differences in accent and focus regarding the reactions to high stress amongst different racial/cultural groups.

Majalefa (1991, p.65) points out that the consistent passivity of the South African black employee hides his high stress levels. In this regard, Watts $(1985$, p.303) states: "It is worrying that the black worker tends to adopt emotional defensive coping strategies such as withdrawal or passivity, when faced with role stress." Van Zyl (1993, p. 38) found that passivity, uncertainty and loneliness are stress emotions most commonly experienced by a group of high-level black employees when subjected to high stress. Supervisors should thus pay attention to the already discussed symptoms and take action should they be noticed.

In a study conducted by Van Zyl (1996, p. 130) on the experience of stress amongst a group of lower level black and white employees involved in manual tasks, results indicated that black employees at lower levels are inclined to lack self-confidence, to be dependent on others, to be passive, to feel uncertain, to be dissatisfied and frustrated and to feel helpless. White employees on the other hand, showed higher scores than the black group on overload and to worry.

Van Zyl (1996, p. 120) also indicated that meanings given to stress symptoms by a group of higher level black employees were generally described in more concrete/ specific terms than their white counterparts. Examples of descriptions of symptoms (with the real meanings in brackets), are:

- Sadness: "To lose someone" (to be sad or tearful)

- Passivity: "Not to participate in sport and cultural activities" (wanting to do something more interesting)

- Inferiority: "To feel small" ( have no self-confidence)

- Depression: "Not having clothes and food" (feeling dejected).

Unfortunately, it is not always easy to spot symptoms of high stress in employees. McGarvey (1995) explains it as follows: "The effects of high stress is often hidden at work because reputations have to be protected. The employee has a fear of failure and all energies are directed towards keeping him going while pretending it is not happening."

In the light of this and of other reasons put forward in the preceding sections, it is clear that a formal process of stress measuring within organizational context is a necessity. This is to ensure that responses from different racial and cultural groups are identified and included in stress measurement and management.

\section{The process of stress measurement within} organizational context

Quick and Quick (1994:99) offer a schematic representation (see Figure 1) of the process of stress measuring in the work situation:

The following aspects of the schematic representation should be emphasised:

- In measuring stress the focus should fall on identifying levels as well as causes of stress. Some consultants and researchers use the causes of stress as indicators of the level of stress experienced by a particular person and/or group (Van Zyl, 1997). Although there is a relation between the level and causes of stress, these two components should not be equated. For example, the frequency of causes forced upon a person may be high, but the person may still possess the ability to handle these demands. This means that the person may probably experience normal levels of stress. Thus, both the level and the causes of stress should be measured.

- It should be determined whether a person and/or group is experiencing normal, high or very high stress. If high stress is experienced, those suffering from it should be exposed to developmental actions (for example stress management courses). Persons experiencing normal stress should, from a cost-effective perspective, not be exposed to stress management courses unnecessarily. Furthermore, investigations (Van Zyl, 1997) have revealed that persons suffering from very high stress usually also suffer from deepseated emotional problems and will probably not benefit from stress management programmes. In such cases, individual therapy would be more beneficial.

- Concerning the measuring of the causes of stress, causes within and outside the work situation should be identified. Some organisations only focus on the identification and management of causes within organizational context. 


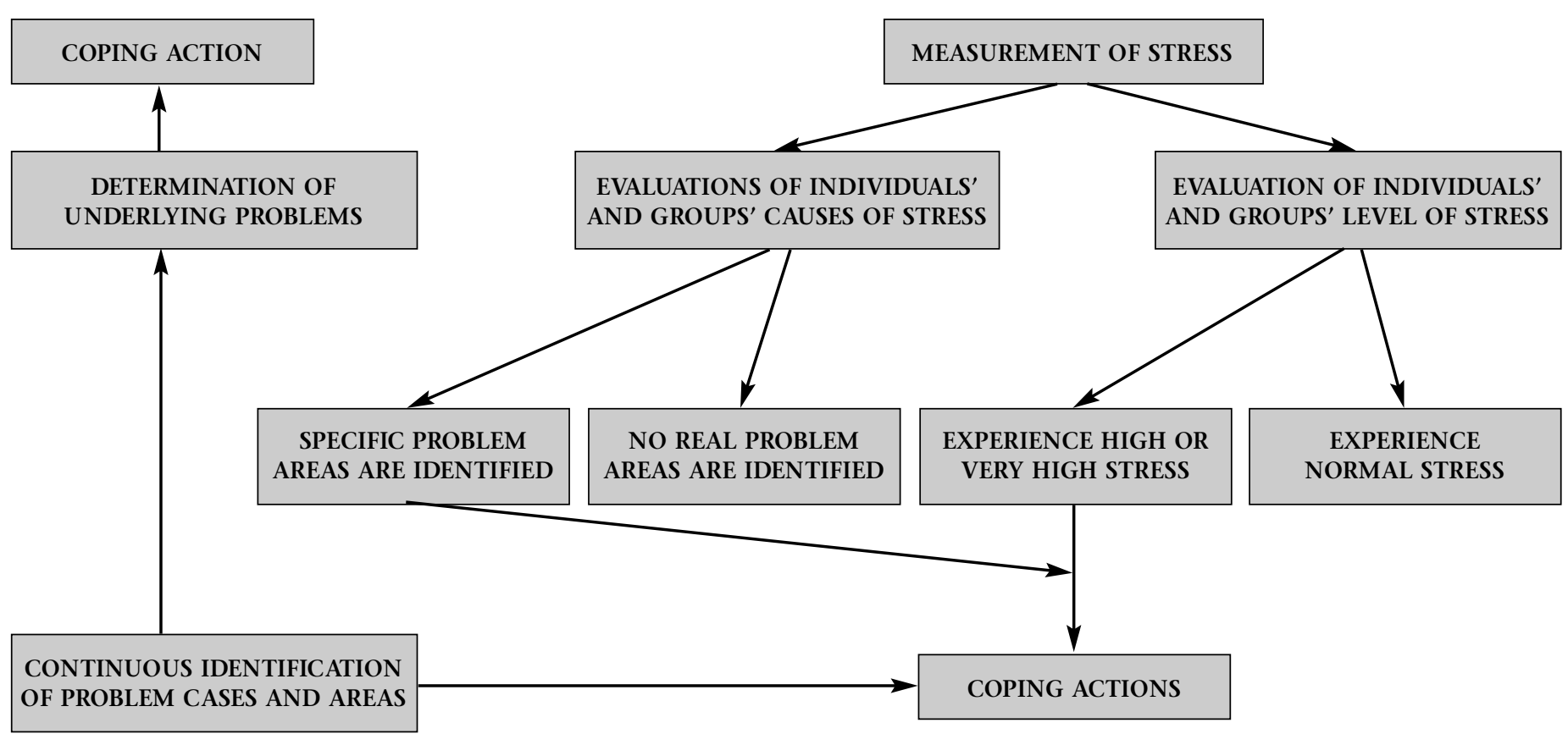

Figure 1: Measuring stress in the work context (Quick \& Quick, 1994, p. 100).

However, the identification and management of problems outside the work situation could contribute greatly to an increase in the quality of life of employees. In this regard actions such as literacy training, medical and housing support, legal advice, bursaries and other forms of educational assistance comes to mind.

- The identification of problems/stressors should be a continuous process within organizations and should not be a once-only occurrence. By implementing the correct method and procedure of measuring, one can ensure that underlying problems are identified and not merely superficial symptoms.

The question now is, what method should be used to measure stress?

\section{Various methods of measuring stress}

Stress can be measured by means of different methods and the most important methods will be discussed next. However, it is important that any stress measuring device should be crossculturaly standardised (in other words be valid, reliable and fair regarding their application on different racial/cultural groups).

- Physiological measurements

Van Zyl (1991, p.100) is of the opinion that the physiological reactions of the individual to stress (as an indication of stress) can be monitored. Thus the degree of secretion of sweat, the breathing rate, skin conductivity, secretion of growth hormones, blinking of the eyes, etc can be analyzed.

Quick and Quick (1984, p. 128) point to the following problems that may be experienced in respect of the use of physiological measuring as an indication of stress within organizations:

- Conducting physiological measurements is often expensive and complicated

- Changes in physiological conditions are not necessarily related to stress

- The results of physiological measurements are not always applicable and reliable.

- Observation

Individuals may be exposed to stressful situations where their behaviour may then be observed (Arnold, Robertson and Cooper, 1995).

Arnold, Robertson and Cooper (1995) state that during observation, attention must also be given to the possibility of observational errors as well as subjective involvement by the observer. Quick and Quick (1984) hold the opinion that observation as a method of measuring stress should at least be implemented along with other approaches to stress measuring, as individual stress cannot always be indicated accurately.

- Behavioural indicators

There are a number of behavioural indicators that can be taken into consideration when determining the amount of stress experienced. Within organisational context, accident, absence and personnel turnover figures may serve as an indication of stress (Cascio, 1998).

Cascio points out that these behavioural indicators do not always manifest (even though the individual may be experiencing high levels of stress), and are in themselves not a suitable method of measuring stress.

- Interviews

Quick and Quick (1994) explain that the non-structured interview in particular may be used successfully as a method of measuring stress. During an unstructured interview, the person is given the opportunity to express his perceptions and feelings regarding his experiences freely. The interviewer however, should use open questions to guide the person with whom the interview is being conducted. Smith (1993) mentions that the greatest advantage of the interview as a means of measuring stress lies in the fact that the interviewer can obtain a great deal of information with regard to important aspects.

The greatest drawbacks of the interview are that it is timeconsuming and that it is not always possible for the interviewer to summarize interview information accurately and effectively.

- Self-evaluation questionnaires

Questionnaires present a means of measuring that can be applied more easily (Van Zyl, 1997).

Self-evaluation questionnaires may be used in various forms. Two commonly used forms are the Semantic Scale and the Likert Scale. Quick and Quick (1994, p. 102) argue that by using a semantic scale, potential stressors within the work situation may be expressed in terms of various feelings. For example, an employee may be asked to describe his work in terms of frustration as opposed to non-frustration, tenseness as opposed to relaxation, etc.

Furthermore, numeric values given to items may give an indication of the degree of stress experienced (Likert Scale). 
Linde, Rothmann and Sieberhagen (1999) add the following important remarks:

- Self-evaluation questionnaires are cost-effective since they can be applied to a whole group of people at a time.

- Self-evaluation questionnaires can present an objective measurement of stress since the person is evaluating himself/herself and since the interpretation of data is not dependent on the subjective judgement of another person (for example the interviewer).

- Since self-evaluation questionnaires are normally quantified, it is easier to compare the scores of different individuals.

With the use of self-evaluation questionnaires, there is a danger that individuals may deny their symptoms or decide to answer the questionnaire in either a favourable or an unfavourable light. Van Zyl and Van der Walt (1994) and Smit (1981) also point out that the validity of selfevaluation questionnaires may vary from situation to situation. Many of the items are often found to be ambiguous and may be perceived as having two possible answers, as in "Yes, but ...."

If the above-mentioned problems are taken into consideration in the design of questionnaires, and if rapport (and therefore co-operation) can be established with the respondent, these problems can (according to Van Zyl and Van der Walt, 1994) be overcome to a large extent.

Where should we start?

When an organization begins to consider stress management and the measuring of stress, a frequent question is "where to start?"

Firstly, Cartwright and Cooper (1997) express the opinion that, all things being equal, supervisory and management personnel should be selected first. Their reason is that these staff members carry significant responsibility for people, a stressor that research has consistently shown to be worse than responsibility for things, and, furthermore, that executives have a greater impact on the economic well-being of an organisation and hence any incompetence at an executive level as a result of stress will probably have more significant results on the organisation's bottom line. Thus, by first of all measuring the level and causes of stress experienced by the supervisory and management personnel, action in accordance with the results can immediately be taken and this can have specific advantages for the organisation.

Secondly, Cartwright and Cooper (1997) advise that one should identify groups of employees in high-stress jobs. These include the following:

- Unusually prolonged deadline pressures.

- Chronic work overload.

- Constant change in requirements, procedures, schedules or even supervisors.

- Frequent physical danger.

- Minimum opportunities to interact with others and thus a lacking of opportunities to build social support networks.

- Highly automated and repetitive tasks.

Thirdly, the above-mentioned authors refer to groups of employees who are particularly susceptible to distress, regardless of their actual work, for instance, very young and inexperienced employees, older employees on a career plateau but still making a worthwhile contribution, recently transferred people and minority group members.

According to Van den Bergh (2001), one effect of new legislation (for instance the New Employment Equity Act) is that many black women suddenly find themselves in managerial positions, sometimes without the necessary skills, experience and support. Black women in managerial positions can therefore also be considered a "risk group" regarding the measurement and handling of stress (Van den Bergh, 2001, p. 15).
Lastly, personnel and productivity criteria, such as abnormal levels of turnover and absenteeism, accidents, escalating costs or a decrease in production, can also be used to identify persons who must be put through the process of measuring and management of stress.

\section{CLOSING REMARKS}

In highly industrialised and affluent countries such as the USA, the UK, Germany or Sweden, the measurement and management of stress is something of a "cherry on top". It is very important, but something that can be postponed until more serious matters have been dealt with. This is not the case in this country.

As a result of the shortage of high-level human resources, managers and professionals are under great pressure; similarly, the skills shortage is creating unique pressures for technicians and skilled workers. New legislation (for instance the Employment Equity Act), affirmative action and the quota systems are creating great and unique distress among workers from different racial/cultural groups. This is intensified and compounded by economic conditions that make life in South Africa an unusually distressful experience. The problems are also intense, extensive and complex enough to rob people of any hope that there will be significant relief even in a future generation.

For these reasons, a system of stress measurement and management - at all levels - is not a luxury in South Africa, or something "nice" to do for humanistic reasons. It is a matter of physical, psychological, economic and social survival. Stress measurement, in particular, can help to address the real problems in a preventive manner.

\section{REFERENCES}

Arnold, J., Robertson, I.T. \& Cooper, C.L. (1995). Work psychology: understanding human behaviour in the workplace ( $2^{\text {nd }}$ ed). London: Clap Ltd.

Bews, G.P. (1988). Work and well-being: An agenda for the 1990's. Washington DC: C. Thomas.

Carstens, L. (1989). Die ontwikkeling en implementering van 'n stresbeheerprogram vir middelvlakbestuurders in ' $n$ diensorganisasie. Unpublished D.Com. thesis, University of the Free State, Bloemfontein.

Cartwright, S., Cooper, C.L. (1997). Managing workplace stress. London: Sage.

Cascio, W.F. (1998). Applied psychology in personnel management (3rd ed). Englewood Cliffs: Prentice-Hall.

Everley, G.S. \& Fieldman, R.H. (1991). Occupational health promotion. New York: Wiley.

Gerber, P., Nel, P.S. \& Van Dyk, P.S. (1994). Mannekragbestuur. Halfweghuis: Southern Books Publishers.

Ivancevich, J.M. \& Matteson, M.T. (1996). Organizational behaviour and management (4th ed). United States of America: Irwin Book Team.

Jacobs, Y. (2001). Die voorspelling van die effektiewe hantering van werkstres by bestuurspersoneel met behulp van persoonlikheidsveranderlikes. Unpublished B.Com. dissertation, University of the Free State, Bloemfontein.

Karasek, R.A. \& Theorell, T. (1990) Healthy work: Stress, productivity and the reconstruction of working life. New York: Basic Books.

Kruger, E. (1988). Dimensional problems of criteria. Journal of Applied Psychology, 40, 1-4.

Levert, T., Lucas, M. \& Ortlepp, K. (2000). Burnout in psychiatric nurses. South African Journal of Pychology, 30 (2), 36-43.

Linde, L.H., Rothmann, S., Sieberhagen, G. (1999). Senior bestuurders in ' $\mathrm{n}$ openbare maatskappy se belewing van loopbaanontwikkeling. Journal of Industrial Psychology, 25 (2), 13-20. 
McGarvey, R. (1995). Op die rand van geestelike uitputting. Finansies en Tegniek, 46-47.

Mojalefa, P. (1991). Black advancement and stress: a literature review. Johannesburg: National Institute for Personnel Research.

National Council for Mental Health. (1991). Stress and health. Johannesburg: National Institute for Personnel Research.

Nykodym, D. \& George, R. (1989). Stress and coping. Issues in mental health, 14 (4), 399-400.

Pienaar, J.W. (1998). Verskille in werkstres en psigiese uitbranding tussen blanke- en swart middelvlak-bestuurspersoneel in 'n SuidAfrikaanse diensorganisasie. Unpublished B.Com. dissertation, University of the Free State, Bloemfontein.

Quick, J.C. \& Quick, J.D. (1994). Organizational stress and preventive management. New York: McGraw-Hill.

Quick, J.C., Murphy, L.R. \& Hurrel, J.J. (1992). Stress and wellbeing at work. Assessments and interventions for occupational mental health. Washington DC: American Psychological Association.

Rehabilitation in South Africa. (1991). Stress issues. Johannesburg.

Schaufeli, W.B., Maslach, C. \& Marck, T. (1993). Professional burnout: recent developments in theory and practice. London: Taylor and Francis.

Smit, G.J. (1981). Psigometika. Pretoria: HAUM.

Smith, J.C. (1993). Understanding stress and coping. New York: MacMillen.

Strumpher, R. (1995). Die verskil in voorkoms van stres en uitbranding by bepaalde helpende professies van die SAW.
Unpublished B. Com. dissertation, University of Pretoria, Pretoria.

Van den Bergh, H. S. (2001). Stres en die beroepsvrou: 'n fortigene ondersoek. D. Phil. thesis, University of the Free State, Bloemfontein.

Van Selm, S. (1990). Stress and anxiety. Journal of Social Behaviour, 9 (2), 199-218.

Van Zyl, E.S. (1991). Die ontwikkeling van 'n meetinstrument van werkstres vir hö̈vlak werknemers. Ongepubliseerde B.Com.proefskrif, Universiteit van Pretoria, Pretoria.

Van Zyl, E.S. (1993). Stres, soos ervaar deur die hoëvlak swart werknemers in Suid Afrika. Tydskrif vir Bedryfsielkunde, 19 (3), 36-39.

Van Zyl, E.S. (1996). The experience of stress among high level employees. Acta Academica, 28 (2), 111-124.

Van Zyl, E.S. (1996). The experience of stress in a group of lower level black and white employees involved in manual tasks. South African Journal of Management Sciences, 18 (3), 118-134.

Van Zyl, E.S. (1997). Die verband tussen stres en organisasieklimaat by ' $\mathrm{n}$ groep middelvlak bestuurders in die finansiële sektor. Tydskrif vir Geesteswetenskappe, 37 (2), 138-143.

Van Zyl, E.S. \& Van der Walt, H.S. (1994). Die ontwikkeling van ' $\mathrm{n}$ meetinstrument van werkstres. Journal of Industrial Psychology, 20 (4), 22-28.

Watts, J. C. (1985). Black managers and their work colleagues in selected industrial organizations in Natal. D. Phil. thesis, University of Natal, Durban. 